\title{
Information Infrastructure as Rhetoric: Tools for Analysis
}

Nathan R. Johnson

Department of English, Purdue University

Lafayette, IN USA

Poroi 8, 1 (April 2012)

Our lived worlds are saturated in information infrastructure, the systematized technologies that organize the information that publics use to inform themselves about subjects as diverse as politics or energy consumption (Bowker \& Star, 1999). Infrastructure provides the invisible scaffolding for discovery, dissemination, and access to information. Since information is concomitant with knowledge, criticality, and awareness, the form of infrastructure has real consequences for the forms of public communication, knowledge, and political life that are already being studied by rhetoricians.

A notable example of infrastructural significance lives in one of our own knowledge technologies: the academic databases that provide access to the scholarship of our peers (Borgman, 2007). Database vendors benefit from their ability to organize academic journals that provide access to the work of scholars. The intellectual work of creating these databases builds in assumptions about how the world of scholarship should be organized. For instance, many database vendors provide access to their content through subject heading lists that were originally constructed at the turn of the $2 \mathrm{O}^{\text {th }}$ century by Librarians of Congress. Infrastructure materializes the situated knowledge work of the past and uses it to organize the present and future. The work of building infrastructure builds technological momentum that constructs regimes of public information (Hughes, 1994).

The construction of these technological monsters should be a site of rhetorical intervention. Because of its apparent vastness, though, infrastructure can outwardly seem to be a daunting object for study. Often when discussing infrastructure, we begin by listing the numerous expressions of technology that hang together as a working system (Bowker et al., 2010). A vendor's database infrastructure could include the numerous computer systems, classifications, wiring, software, and interfaces that provide access to scholarly work. Yet infrastructure condenses at only a handful of technological points that enable the entire monster to work as a whole. These technological points aid analysis.

Information infrastructure consists of the classifications, standards, protocols, and algorithms that organize information and communication 
practices. Subject heading lists organize content areas in fairly straightforward ways. They mediate the discovery of journal articles and books. But as digital systems have become more complex, so have the forms of infrastructural control. Search algorithms designed by Google limit the intellectual world of novice searchers. Metadata standards devised for information sharing via Twitter refract the information sharing messages of its users, and while growing bodies of research are investigating the potentials of using Twitter as a communication tool, much less work is being done to look at information infrastructures like Twitter as an object of study.

Communication scholars need to start looking at infrastructure instead of through it. Investigating the rhetoric of classifications, standards, protocols, and algorithms is an important part of understanding modern rhetorics.

I offer three different approaches to rhetorically intervening in information infrastructure. The first is through genealogies (Foucault, 1980; Johnson, 2009). By conducting detailed historical investigations into the construction of infrastructure, scholars can gain an understanding of the situated rhetorics that become embodied technologies. This type of work would chronicle the work of infrastructural developers who build infrastructure. For instance, one might chart the trajectories involved in the user studies that inform the algorithms of Google's search.

The second approach involves rhetorical ethnography. By selfreflectively becoming a part of the lifeworld of an infrastructure, scholars can better understand what it means to live within infrastructure. This type of investigation involves entering into perhaps familiar territory with new eyes. This type of study would combine the rich analytic tools of the rhetorical tradition with the ethnographic tools popular in anthropology. A study might consist of using infrastructure like Twitter while interrogating how its organizing mechanisms alter interactions that may have been shared through other means.

The third approach involves protocological hacking (Galloway, 2004). By becoming builders of infrastructure, rhetoricians productively take the affirmative position of understanding the classificatory, standardizing, protocological, and algorithmic concepts built into information infrastructuring. We build our own infrastructural rhetorics to better understand infrastructure. For instance, consider the value of reimagining the scholarship of rhetorical studies through infrastructure adapted to understanding the contemporary state of the discipline instead of serving the needs of academic database vendors. Consider the value of search and discovery technologies built from the disciplinary vantage point of a rhetorician rather than an information scientist.

Work within the rhetoric of science and technology currently exists that comes close to an investigation of infrastructure. Foundational studies of citation, statistics, and mathematics are already investigating the components of infrastructure (Bazerman, 1988; R. Connors, 1998; R. J. Connors, 1999; McCloskey, 1998; Reyes M., 2004). The related discipline of Science Studies also teems with similar studies. The rich 
amalgam of these previous studies can serve as the foundations for a rhetorical study of information infrastructure. In the "age of information" when "cyberinfrastructure" has become a significant source of power for modern institutions, rhetoricians can do important work to describe the tropes of infrastructure. This essay is a call for rhetorical intervention into that information infrastructure.

\section{References}

Bazerman, C. 1988. Shaping written knowledge: The genre and activity of the experimental article in science. Madison, WI: University of Wisconsin Press.

Borgman, C. L. 2007. Scholarship in the digital age: Information, infrastructure, and the internet. Cambridge: MIT Press.

Bowker, G. C., \& Star, S. L. 1999. Sorting things out: Classification and its consequences. Cambridge: MIT Press.

Bowker, G.C., Baker, K., Millerand, F. \& Ribes, D. 2010. Toward information infrastructure studies: Ways of knowing in a networked environment. In J. Hunsinger, L. Klastrup, \& M. Allen (Eds.), International handbook of Internet research. Dordrecht; Springer, 97-117.

Connors, R.J. 1998. The rhetoric of citation systems, Part I: The development of annotation structures from the renaissance to 1900. Rhetoric Review, 17(1), 6-48.

Connors, R. J. 1999. The rhetoric of citation systems-Part II: Competing epistemic values in citation. Rhetoric Review, 17(2), 219-245.

Foucault, M. 1980. Nietzsche, Genealogy, History. In D.F. Bouchard (Ed.), Language, counter-memory, practice: Selected essays and interviews. Ithaca: Cornell University Press, 139-165.

Galloway, A.R. 2004. Protocol: How control exists after decentralization. Cambridge: MIT Press.

Hughes, T. P. 1994. Technological Momentum. In M.R. Smith \& L. Marx (Eds.), Does technology drive history? The dilemma of technological determinism. Cambridge: MIT Press, 101-113.

Johnson, N. R. 2009. Technical documents as rhetorical agency. Archival Science, 8(3), 199-215.

McCloskey, D. 1998. The Rhetoric of Economics. Madison, WI: University of Wisconsin Press.

Reyes M. 2004. The rhetoric in mathematics: Newton, Leibniz, the calculus, and the rhetorical force of the infinitesimal. Quarterly Journal of Speech, 90(2), 163-188. 